\title{
In search of the unexpected: the first finding of an islandic population of the noble crayfish Astacus astacus in Greece redefines its distribution
}

\author{
Ioannis Karaouzas ${ }^{*}(\mathbb{D}$, Ioannis Leris $@$, Yiannis Kapakos@, Nektarios Kalaitzakis@, \\ Konstantinos Fytilis@, Petros Kouraklis and Eleni Kalogianni® \\ Institute of Marine Biological Recourses and Inland Waters, Hellenic Centre for Marine Research, 46.7km Athens-Sounio Av., 19013 \\ Anavyssos, Attica, Greece
}

Received: 8 November $2021 /$ Accepted: 23 December 2021

\begin{abstract}
This contribution presents the first record of the noble crayfish Astacus astacus (Linnaeus, 1758) in Euboea (Evia) Island, Greece. The crayfish was found during a fish monitoring expedition in the upper Mesapios River, in a reach that maintains flow throughout the year, while most of the river length desiccates completely during the dry season. The finding of $A$. astacus in an intermittent river of Euboea Island expands the species geographical range and calls for immediate conservation actions to protect its habitat and preserve this vulnerable population.
\end{abstract}

Keywords: Zoogeography / freshwater / new record / IUCN / conservation

Résumé - Cette contribution présente le premier signalement de l'écrevisse noble Astacus astacus (Linnaeus, 1758) dans l'île d'Eubée (Evia), en Grèce. L'écrevisse a été trouvée lors d'une expédition de surveillance des poissons dans le cours supérieur de la rivière Mesapios, dans un tronçon qui maintient le débit toute l'année, tandis que la majeure partie de la longueur de la rivière se dessèche complètement pendant la saison sèche. La découverte d'A. astacus dans une rivière intermittente de l'île d'Eubée étend l'aire de répartition géographique de l'espèce et appelle à des actions de conservation immédiates pour protéger son habitat et préserver cette population vulnérable.

Mots clés : Zoogéographie / eau douce / nouveau record signalement / UICN / conservation

Four freshwater crayfish species are known from Greece: three indigenous; Astacus astacus (Linnaeus, 1758), Austropotamobius torrentium (Schrank, 1803) and Pontastacus leptodactylus (Eschscholtz, 1823), and the non-indigenous Pacifastacus leniusculus (Dana, 1852). The noble crayfish A. astacus in Greece occurs mainly in the mid and upper parts of rivers and streams, with a limited, discontinuous and grouped distribution (Koutrakis et al., 2007; Laggis et al., 2017; Perdikaris et al., 2017). Astacus astacus is the most widespread species compared to the other native crayfish species of Greece; however its range has been reduced significantly during the last decades (Koutrakis et al., 2007; Perdikaris, 2009).

Today, Astacus astacus is known from Central and Western Macedonia, Epirus, Thessaly and Central Greece (Sterea Ellada), forming three main, disconnected distribution zones, and from the Peloponnese, where it is found only in two

\footnotetext{
${ }^{*}$ Corresponding author: ikarz@hcmr.gr
}

mountain subalpine lakes, in the north part of the peninsula (Laggis et al., 2017; Perdikaris et al., 2017) (Fig. 1). Agricultural intensification, rural development, eutrophication, organic and chemical pollution, habitat and hydromorphological degradation, as well as the crayfish plague caused by Aphanomyces astaci Schikora 1906 with reported incidents in 1982, 1992 and 2004 (Koutrakis et al., 2007; Perdikaris et al., 2017) have caused the species' population decline and fragmentation in Greece.

In this contribution, $A$. astacus is reported for the first time in Euboea (Evia) Island, thus expanding its distribution boundaries and enhancing knowledge of the zoogeography of the freshwater crayfish fauna of Greece. A population of about 15 individuals was found in the upper reach of the Mesapios River main stem on 14 September 2021 (Fig. 1); specimens were photographed alive on-site and released back into the water (Fig. 2). Benthic habitat is mainly composed of cobbles, pebbles, and gravel, and abundant coarse particulate organic matter (i.e., leaf litter, twigs, etc.) 
I. Karaouzas et al:: Knowl. Manag. Aquat. Ecosyst. 2022, 423, 1

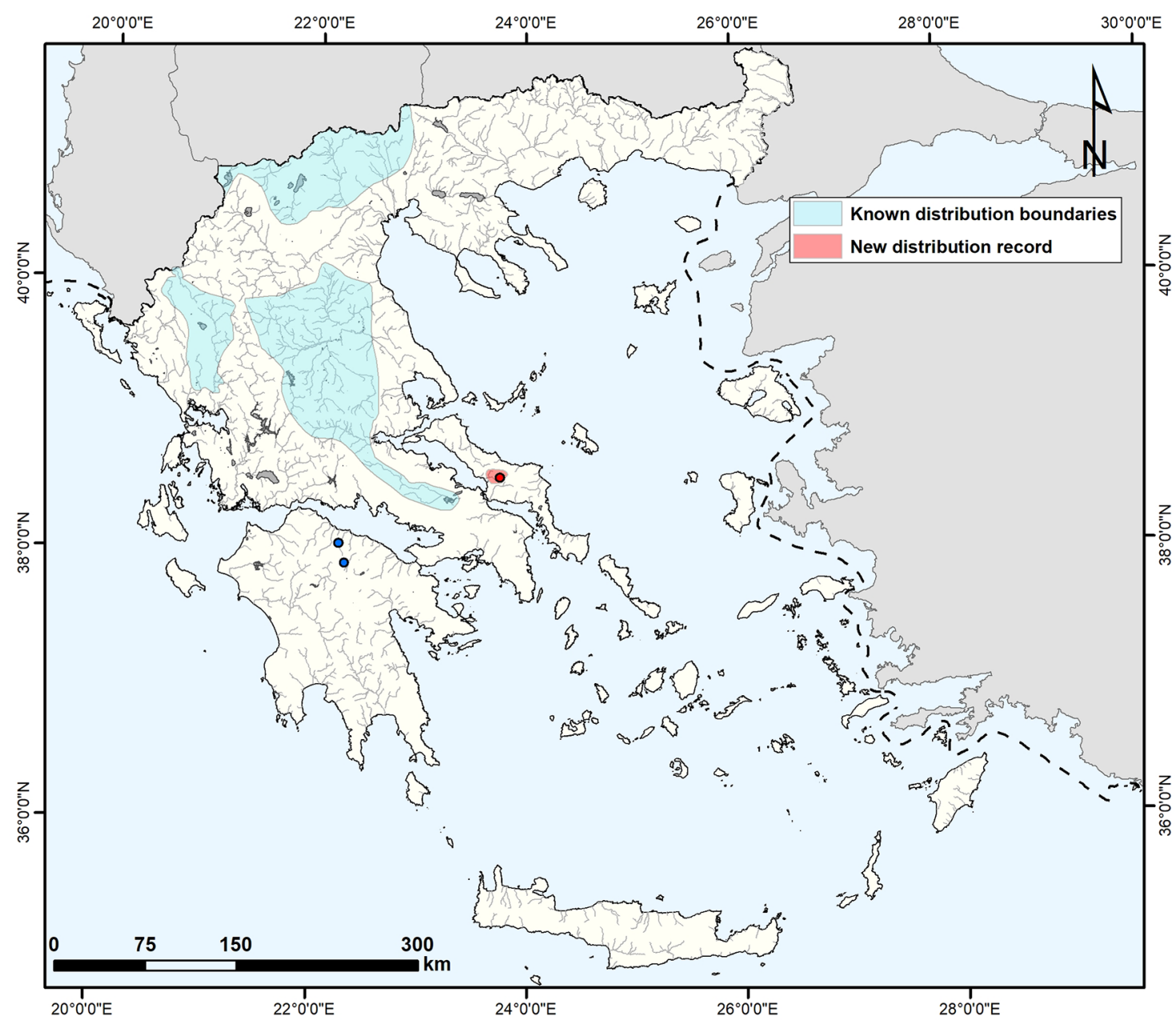

Fig. 1. Distribution map of Astacus astacus in Greece. Light blue shaded areas and dark blue dots indicate known distribution boundaries and isolated records respectively of the species (Perdikaris et al., 2017). Red dot and red shaded area indicates the new locality of $A$. astacus in Euboea Island.

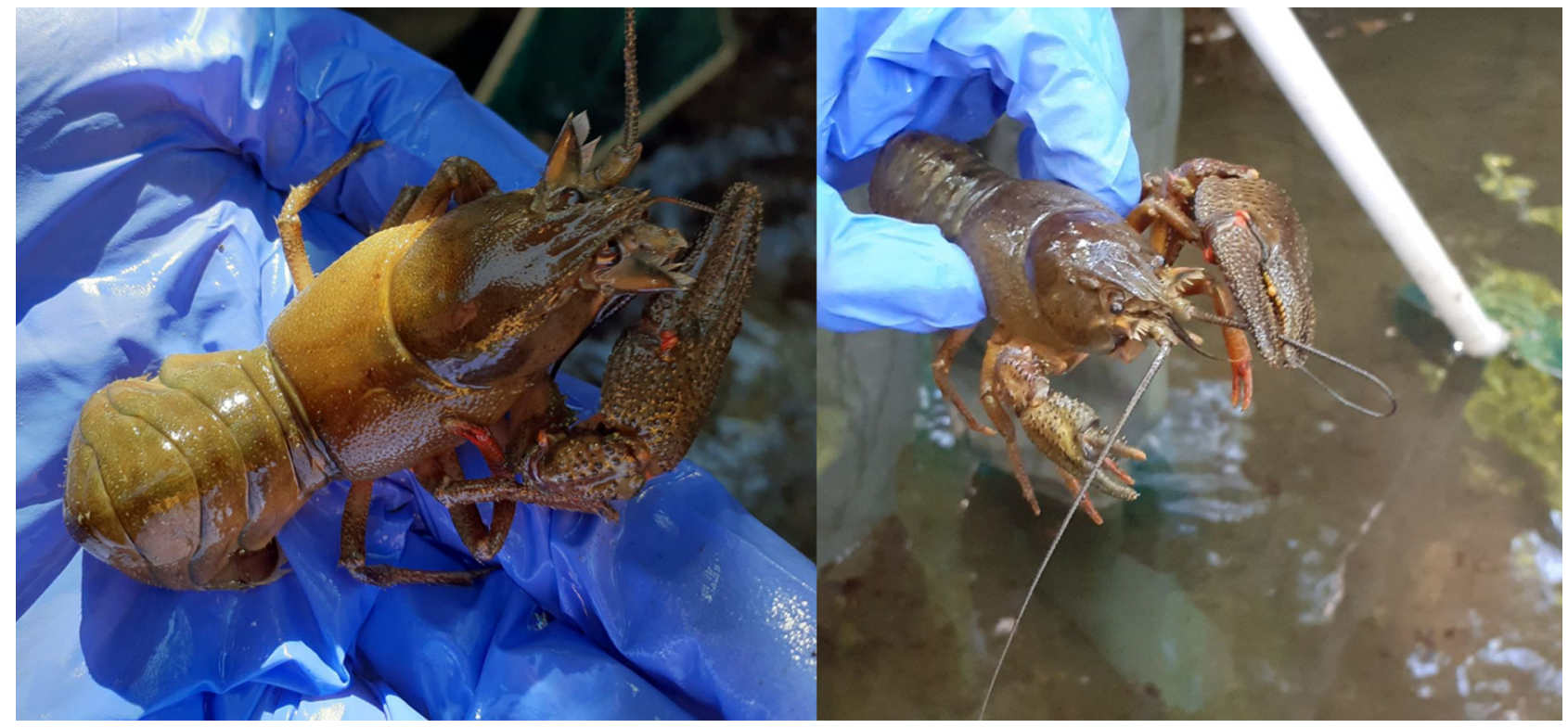

Fig. 2. Astacus astacus individuals from Mesapios River, Euboea Island. 


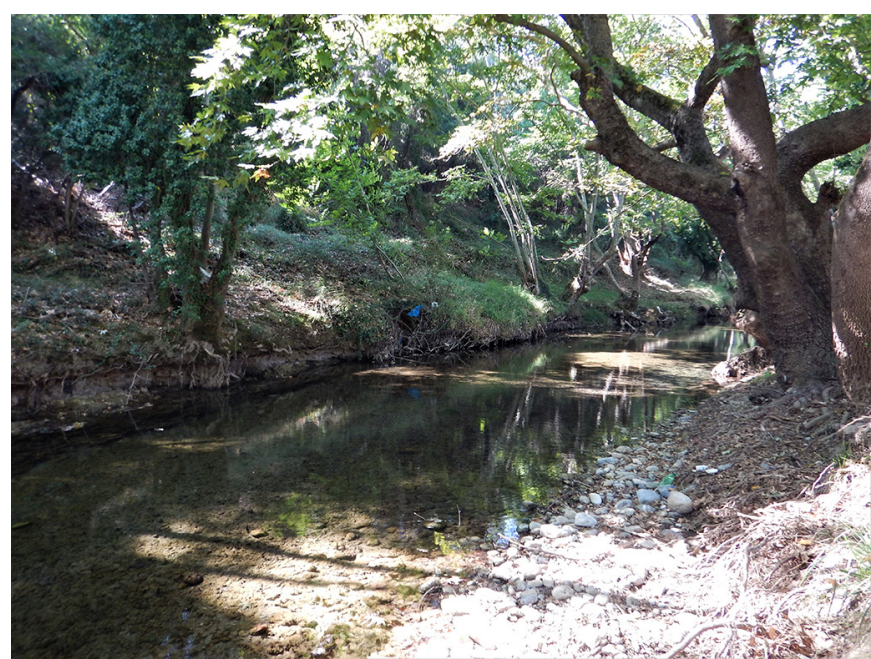

Fig. 3. Habitat of Astacus astacus at Mesapios River, Euboea Island.

Table 1. Physicochemical and chemical parameters and habitat characteristics of the A. astacus collection site in Mesapios River, Euboea Island.

\begin{tabular}{|c|c|c|}
\hline Parameters (Units) & Min-Max & Mean \\
\hline $\mathrm{pH}$ & $6.88-7.89$ & 7.57 \\
\hline Water temperature $\left({ }^{\circ} \mathrm{C}\right)$ & $13.1-26.47$ & 17.42 \\
\hline Conductivity $(\mu \mathrm{S} / \mathrm{cm})$ & $503-591$ & 550 \\
\hline TDS (mg/l) & $134-282$ & 269 \\
\hline Salinity (ppt) & $0.22-0.29$ & 0.265 \\
\hline Turbitity (NTU) & $0.28-2.72$ & 1.67 \\
\hline D.O. $(\%)$ & $73.5-115.4$ & 96 \\
\hline D.O. $(\mathrm{mg} / \mathrm{l})$ & $7.11-11.7$ & 9.56 \\
\hline $\mathrm{BOD}(\mathrm{mg} / \mathrm{l})$ & 0 & 0 \\
\hline $\mathrm{Cl}(\mathrm{mg} / \mathrm{l})$ & $17.9-20.94$ & 19.42 \\
\hline $\mathrm{Si}(\mathrm{mg} / 1)$ & $5.51-6.07$ & 5.79 \\
\hline $\mathrm{N}-\mathrm{NO}_{2}(\mathrm{mg} / \mathrm{l})$ & $0.001-0.002$ & 0.0015 \\
\hline $\mathrm{N}-\mathrm{NO}_{3}(\mathrm{mg} / \mathrm{l})$ & $1.27-2.02$ & 1.64 \\
\hline $\mathrm{N}-\mathrm{NH}_{4}(\mathrm{mg} / \mathrm{l})$ & $0.009-0.013$ & 0.011 \\
\hline $\mathrm{DIN}(\mathrm{mg} / \mathrm{l})$ & $1.28-2.03$ & 1.66 \\
\hline $\mathrm{TN}(\mathrm{mg} / \mathrm{l})$ & $1.42-2.16$ & 1.79 \\
\hline $\mathrm{P}-\mathrm{PO}_{4}(\mathrm{mg} / \mathrm{l})$ & $0.001-0.003$ & 0.002 \\
\hline $\mathrm{TP}(\mathrm{mg} / \mathrm{l})$ & $0.003-0.005$ & 0.004 \\
\hline Cobbles and pebbles $(16-256 \mathrm{~mm})(\%)$ & 50 & \\
\hline Gravel and sand (2-64 mm) (\%) & 30 & \\
\hline Mud $(0.0625-2 \mathrm{~mm})(\%)$ & 10 & \\
\hline Silt and clay $(<0.0625 \mathrm{~mm})(\%)$ & 10 & \\
\hline Aquatic vegetation (\%) & 40 & \\
\hline Canopy cover $(\%)$ & 80 & \\
\hline Physicochemical quality & Good-High & Good \\
\hline
\end{tabular}

from the woody riparian zone (mainly Platanus orientalis L.) as well as algae, thus indicating eutrophic conditions (Fig. 3). The fish fauna at the upper Mesapios River basin is dominated by the barbel Barbus sperchiensis Stephanidis, 1950 followed, in much smaller numbers, by the chub Squalius sp. Evia.

Mesapios River is situated in the southwestern part of Central Euboea, and has a total length of $34 \mathrm{~km}$ which consists of three main branches; S1 of $4.22 \mathrm{~km}$ length, S2 (Makrimalis stream) with $9.25 \mathrm{~km}$ length and S3 with $20.53 \mathrm{~km}$ length. The total catchment area is $216 \mathrm{~km}^{2}$. According to the River Basin Management Plans (Ministry of Environment \& Energy, 2018), the average annual natural runoff has been estimated at 81.90 million $\mathrm{cm}^{3} /$ year. The dry period in the area starts from mid-April and lasts until mid-October, thus for six months there is limited precipitation. Most of its length is of ephemeral and intermittent character; it retains flows only for a couple of kilometers at the upper part of S3 where the isolated population of $A$. astacus was found.

Physicochemical parameters at the sampling location were measured with a HANNA Multiparameter Water Quality Meter - HI98194, while water samples were collected and transferred to HCMR laboratories for nutrient and major ion analysis. The physicochemical, chemical and habitat characteristics of the sampling locality are presented in Table 1. Overall, the physicochemical quality of the sampling site varies from good to high, as classified according to the physicochemical quality index (Skoulikidis et al., 2006).

The finding of a crayfish species in Euboea Island was greatly unanticipated, as until today there have not been any historical records or any indication suggesting the presence of crayfish in the Island as well as in any Greek Island. As it can be seen from Figure 1, the southernmost record of $A$. astacus (except the two isolated populations in the Peloponnese peninsula) was at Kifissos River - Yliki Lake system (for details see Perdikaris et al., 2017), which is adjacent to the Mesapios river basin (Fig. 1). The island became isolated from the mainland 5500 years ago (Mariolakos and Bantekas, 2002) from which it is nowadays separated by the Euboean Gulf. The population of $A$. astacus in the Mesapios River is possibly a remnant of a previously more extended population network. Also, the noble crayfish population in Mesapios River is confined in a small section of the stream that retains flow throughout the year, while upstream and downstream there is no flow for most of the year. Anthropogenic interventions such hydraulic works (e.g., dams, weirs, etc.), water mismanagement, pollution, and hydromorphological degradation have possibly extirpated $A$. astacus populations from most of the Mesapios basin, as well as possibly from adjacent basins. Though it is highly unlikely, a translocation of the species in Mesapios River, cannot be ruled out, since there have been many cases of such practices in Greece (Laggis et al., 2017; Perdikaris et al., 2017), often from locals or fishers without scientific guidance or governmental licenses, with such introductions often substantially impairing local biodiversity. Thus, the origin of the A. astacus population in Euboea Island may be only resolved with population level molecular analysis. The genetic diversity of the A. astacus populations of the Southern Balkans is high (Gross et al., 2021), with Greece representing the older center of expansion/glacial refugium compared to the eastern Black Sea and Western Balkans, with eight putative genetic barriers been identified, highlighting the role of geographic landscape and translocations (Laggis et al., 2017).

Indigenous crayfish species are declining in Europe at alarming rates (Edsman et al., 2010; Kouba et al., 2014; Maguire et al., 2018). The noble crayfish is listed by the IUCN as a Vulnerable species (Edsman et al., 2010). It is also listed in the Appendix III of the Bern Convention and in 
Appendix V of Habitat Directive 92/43/EC. The fragmented nature of the population in Euboea Island restricted in a small section of the river, calls for targeted conservation management actions to ensure the protection and survival of this A. astacus population should be a conservation priority. Furthermore, rigorous and long-term monitoring of the Euboea $A$. astacus population with both conventional field surveys and the more sensitive and less invasive eDNA method, typically applied to monitor native as well as alien crayfish (King et al., 2022) is also required.

Acknowledgements. This contribution represents incidental observations and recordings made during the National Water Framework Directive monitoring project funded by the Ministry of Environment and Energy and by the European Union. We thank the two anonymous reviewers for their valuable comments.

\section{References}

Edsman L, Füreder L, Gherardi F, Souty-Grosset C. 2010. Astacus astacus. The IUCN Red List of Threatened Species 2010: e.T2191A9338388. http://dx.doi.org/10.2305/IUCN.UK2010-3. RLTS.T2191A9338388.en

Gross R, Lovrenčić L, Jelić M, Grandjean F, ðuretanović S, Simić V, et al. 2021. Genetic diversity and structure of the noble crayfish populations in the Balkan Peninsula revealed by mitochondrial and microsatellite DNA markers. PeerJ 9: e11838

King, AC, Krieg R., Weston A, Zenker AK. 2022. Using eDNA to simultaneously detect the distribution of native and invasive crayfish within an entire country. $J$ Environ Manag 302: 113929
Kouba A, Petrusek A, Kozák P. 2014. Continental-wide distribution of crayfish species in Europe: update and maps. Knowl Manag Aquat Ecosyst 413: 05

Koutrakis E, Perdikaris C, Machino Y, Savvidis G, Margaris N. 2007. Distribution, recent mortalities and conservation measures of crayfish in Hellenic fresh waters. Bull Fr Pêche Piscic 385: 25-44

Laggis A, Baxevanis AD, Charalampidou A, Maniatsi S, Triantafyllidis A, Abatzopoulos TJ. 2017. Microevolution of the noble crayfish (Astacus astacus) in the Southern Balkan Peninsula. BMC Evol Biol 17: 122

Maguire I, Klobučar G, Žganec K, Jelić M, Lucić A, Hudina S. 2018. Recent changes in distribution pattern of freshwater crayfish in Croatia: threats and perspectives. Knowl Manag Aquat Ecosyst 419: $1-12$

Mariolakos I, Bantekas I. 2002. Paleogeographical evolution of Evia Island. In: Kalemi-Kinitro E. (Ed.), Evia and Skiros: Historical documents, 16-20 (in Greek)

Ministry of Environment \& Energy. 2018. 1st Update of River Basin Management Plans - River Basin District of Eastern Central Greece (EL 07). Available at http://wfdver.ypeka.gr/el/project/ approved-el07-00-1revision-summary-en/

Perdikaris C. 2009. Biology and distribution of the populations of crayfish species in the freshwaters of Greece, $\mathrm{PhD}$ thesis. University of the Aegean (in Greek), Greece

Perdikaris C, Konstantinidis E, Georgiadis C, Kouba A. 2017. Freshwater crayfish distribution update and maps for Greece: combining literature and citizen-science data. Knowl Manag Aquat Ecosyst 418: 51

Skoulikidis N, Amaxidis Y, Bertahas I, Laschou S, Gritzalis K. 2006. Analysis of factors driving stream water composition and synthesis of management tools - a case study on small/medium Greek catchments. Sci Total Envir 362: 205-241

Cite this article as: Karaouzas I, Leris I, Kapakos Y, Kalaitzakis N, Fytilis K, Kouraklis P, Kalogianni E. 2022. In search of the unexpected: the first finding of an islandic population of the noble crayfish astacus astacus in greece redefines its distribution. Knowl. Manag. Aquat. Ecosyst., 423, 1. 